\title{
Dynamic response of a mud snail Nassarius sinusigerus to changes in sediment biogeochemistry
}

\author{
N. Eden, T. Katz, D. L. Angel* \\ Israel Oceanographic and Limnological Research, National Center for Mariculture, PO Box 1212, Eilat 88112, Israel
}

\begin{abstract}
It has been widely documented that point sources of organic enrichment elicit abundance peaks in the distribution of benthic opportunistic species. However, the temporal dimension of such phenomena has not been examined. In this study, we explored the dynamic relationship between the seasonal distribution pattern of the mud snail Nassarius sinusigerus and the geochemical conditions of the sediment along an organic enrichment gradient adjacent to a commercial fish farm. Cluster analysis of total dissolved sulfides (TDS), dissolved oxygen (DO) and organic matter $(\mathrm{OM})$ revealed 3 distinct groups: 'highly', 'moderately' and 'slightly' impacted sediments. The seasonal distribution of $N$. sinusigerus along a transect away from the fish farm indicated that a peak in snail abundance was associated with the moderately impacted sediments, occurred between 20 and $80 \mathrm{~m}$ from the center of the farm, and corresponded to [DO] $>0.3 \mathrm{ppm}$ and [hydrogen sulfide] $<1 \mu \mathrm{M}$. When the sediment conditions near the farm deteriorated during summer, the peak in snail abundance shifted away from the farm. An improvement in sediment conditions during the following winter enabled the migration of $N$. sinusigerus toward the farm. The factor drawing $N$. sinusigerus toward the farm was probably food availability, as suggested by the strong attraction of the snails to the sediments and to annelids below the fish cages. This study suggests that the distribution of $N$. sinusigerus around fish farms is determined by the balance between the attraction of the gastropod to the organically enriched sediments below the fish cages and deterrence due to deleterious sediment geochemistry (mainly anoxia and sulfides). As such, the distribution of $N$. sinusigerus may serve as an indicator of sediment conditions.
\end{abstract}

KEY WORDS: Aquaculture - Macrobenthos - Gastropods - Organic matter - Hydrogen sulfide · Hypoxia $\cdot$ Red Sea

Resale or republication not permitted without written consent of the publisher

\section{INTRODUCTION}

The discharge of feces and waste food from net cage aquaculture often leads to organic enrichment which alters the physical and chemical properties of the underlying and nearby marine sediments (Gowen et al. 1991, Holmer \& Kristensen 1992, 1996). The region of 'impacted' sediments has been traditionally characterized by significantly higher levels of organic matter, porewater hydrogen sulfide, ammonia and phosphate and lower levels of dissolved oxygen and redox potential (Beveridge 1996, Pearson \& Black 2001). Changes in sediment geochemistry below commercial fish farms generally lead to reduction and disappearance of many sensitive benthic species and an increase in the abundance of eurytolerant species (Brown et al. 1987, Tsutsumi et al. 1990, Weston 1990, Findlay et al. 1995). The Pearson \& Rosenberg (1978) model of macrobenthic succession along organic enrichment gradients shows that the abundance of 1 or 2 opportunistic species increases up to a maximum ('peak of opportunists') at a given distance from a point-source of organic input. Thereafter, abundances gradually decrease to lower levels characteristic of unenriched sediments (Swartz et al. 1986, Weston 1990, Ferraro et al. 1991, Tsustsumi et al. 1991).

Organic loading rates to sediments under fish cages and the subsequent geochemical changes vary seasonally, since aquaculture feeding regimes closely corre- 
spond to ambient water temperatures (Holmer \& Kristensen 1992, 1996, Angel et al. 1995). It has been suggested that temporal changes in sediment conditions may lead to changes in the position of the 'peak of opportunists' (Pearson \& Rosenberg 1978, Morely 1995, Karakassis et al. 2000). This distance, with respect to the source of organic enrichment, could serve as a means of assessing the extent of impacted sediments. However, to the best of our knowledge, such temporal/spatial patterns have not been demonstrated to date.

The presence of the mud snail Nassarius (Niotha) sinusigerus (A. Adams. 1852) in sandy sediments and seagrass beds in the Gulf of Aqaba was described by Singer \& Mienis (1997), yet the factors affecting this snail's distribution and abundance were not addressed. We have observed large abundances of $N$. sinusigerus on the seafloor in the vicinity of the commercial fish farm 'Ardag' in the northern Gulf of Aqaba, Red Sea, since 1995. In this study we documented the distribution of $N$. sinusigerus and corresponding sediment geochemistry along a horizontal transect from below the fish cages to an unaffected area during 4 consecutive seasons in 1998 to 1999. Moreover, we examined the possibility that the distribution of the mud snail was influenced by its attraction to the increased abundance of food around the fish farm. Our results lend support to the hypothesis that the position of the peak of opportunists tracks temporal changes in sediment geochemistry, as proposed in the Pearson \& Rosenberg (1978) model.

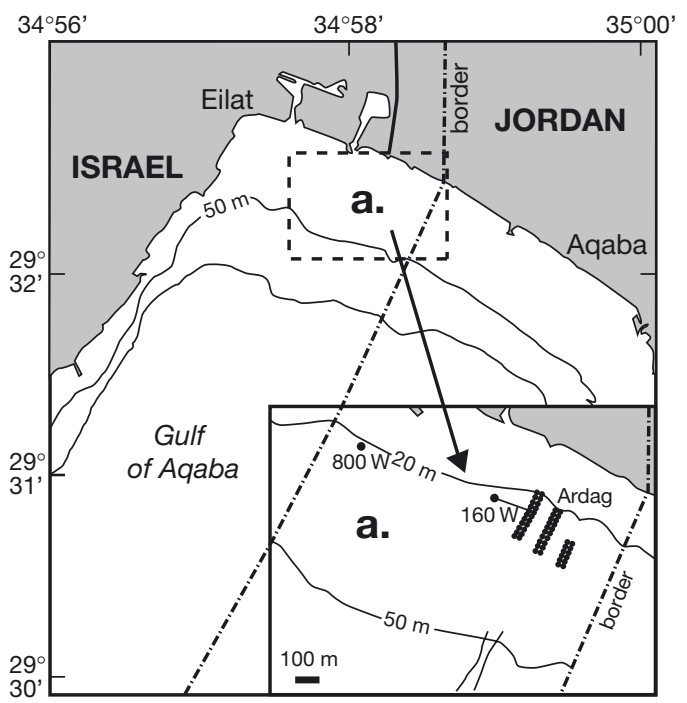

Fig. 1. Map of study area (a) in the Gulf of Aqaba. Transect line started from below western pontoon of the 'Ardag' fish farm (bottom inset) and extended $160 \mathrm{~m}$ westward $(160 \mathrm{~W})$, with sampling stations marked at $20 \mathrm{~m}$ intervals; reference station $(800 \mathrm{~W})$ was established $800 \mathrm{~m}$ west of the farm. All sampling stations were at $24 \mathrm{~m}$ depth; 20 and $50 \mathrm{~m}$ depth contour lines are indicated

\section{MATERIALS AND METHODS}

Study site. The 'Ardag' fish farm is situated at the northern end of the Gulf of Aqaba (Fig. 1) near the Israel-Jordan border. The mean annual current velocity is less than $10 \mathrm{~cm} \mathrm{~s}^{-1}$, although in winter the flow rate may occasionally be as rapid as $35 \mathrm{~cm} \mathrm{~s}^{-1}$ (Brenner et al. 1988, 1991). The dominant component of the flow is east to west However, there are frequent erratic changes in both flow direction and velocity. The water temperature ranges from $21^{\circ} \mathrm{C}$ in winter to $26^{\circ} \mathrm{C}$ in summer (Reiss \& Hottinger 1984, p. 48-55). The 'Ardag' farm consists of 3 parallel pontoons (pontoon length 150 to $200 \mathrm{~m}$ ), each with 10 pairs of cylindrical floating net cages (mean dimensions 13 m diameter, $10 \mathrm{~m}$ deep) moored perpendicular to the predominant current direction (Fig. 1). The major fish species reared in the cages is gilthead seabream Sparus aurata, stocked at between 20 and $25 \mathrm{~kg} \mathrm{~m}^{-3}$. The natural, unenriched sediments near the farm consist of fine sand that supports a wide variety of invertebrates and Halophila stipulacea (seagrass) beds (Fishelson 1971). The organically enriched sediments below the fish cages are often covered by microbial mats that consist mainly of benthic sulfur bacteria (Beggiatoa spp.) and cyanobacteria (Angel et al. 1995).

Water temperature, current measurements and fish feeding. Water temperature $\left( \pm 0.5^{\circ} \mathrm{C}\right)$ was recorded in this study using a Suunto Companion diving computer. We moored an InterOcean S4 current meter $30 \mathrm{~m}$ west of the farm at $21 \mathrm{~m}$ depth, $3 \mathrm{~m}$ above the seafloor, 1 to 4 wk prior to each sampling, and recorded current speed and direction on an hourly basis. The current meter data collected during July 1998 were lost due to a technical mishap. Farm feed data (amount of feed given) were provided by the farm manager as a monthly sum for the entire farm.

Sediment sampling. Sediment samples were collected by divers at 9 stations situated at $20 \mathrm{~m}$ intervals along a marked transect line (24 m depth) starting from directly below the center of the western pontoon of the 'Ardag' fish farm to $160 \mathrm{~m}$ west of this point, and at a reference station located $800 \mathrm{~m}$ west of the farm (Fig. 1). All references to distances from the fish farm relate to the central axis of the fish cages and not the edge of the farm. Sampling was performed in April (spring) 1998, July (summer) 1998, October (autumn) 1998 and February (winter) 1999. We collected 4 sediment cores per station using clear acrylic tubes (30 cm long, $4.5 \mathrm{~cm}$ internal diameter) and rubber stoppers. Geochemical analyses of the sediments commenced within $1 \mathrm{~h}$ of sample collection.

Sediment geochemistry. Vertical profiles of total dissolved sulfides (TDS) and dissolved oxygen (DO) in the sediment cores were recorded by stainless-steel, needle-type electrodes (Microscale Measurements; 
Visscher et al. 1991) mounted on manual micromanipulators (Katz et al. 2002). The TDS results reflect average TDS concentrations in the upper $2 \mathrm{~cm}$ of the sediment, whereas oxygen concentrations relate to DO levels at the sediment surface. $\mathrm{pH}$ was determined using a thin-neck combination glass electrode $(3.5 \mathrm{~mm}$ diameter $277 \mathrm{~mm}$ length, Model \#5990-32 ColeParmer Instruments). The ambient $\mathrm{pH}$ values (not presented) were measured in order to determine TDS concentrations and to calculate porewater concentrations of hydrogen sulfide $\left(\mathrm{H}_{2} \mathrm{~S}\right)$, the toxic species of sulfide, using Table 2.17 in Boyd (1990). Following electrode measurements, the upper $2 \mathrm{~cm}$ of sediment from each core were removed for determination of organic matter by loss-on-ignition (LOI) (through combustion at $450^{\circ} \mathrm{C}$ for $8 \mathrm{~h}$ ).

Snail abundance and weight determinations. At each station, triplicate sediment samples were taken by randomly inserting square $30 \times 30 \times 10 \mathrm{~cm}$ plastic frames into the sediment and collecting all enclosed sediment and snails to a depth of $3 \mathrm{~cm}$ (live snails were not found deeper than $1.5 \mathrm{~cm}$ below the sediment surface). Each sediment sample was placed in a $1 \mathrm{~mm}$ mesh nylon bag and fine sand was removed from the samples by gently shaking the bags while underwater. In the laboratory, samples were transferred to aluminum trays filled with seawater and all live snails in the trays were enumerated. Wet weight determinations (Sartorius L610 balance) were performed for each station on all snails, and when there were $>100$ snails per sample, a random subsample of 100 snails was weighed. Following enumeration, snails were taken back to the sea and released.

Nutritional behavior of Nassarius sinusigerus. In order to evaluate the possibility that the changes in snail distribution, with respect to the fish farm, were related to feeding, a snail 'hunger bioassay' (McKillup \& Butler 1983) was employed. In the bioassay, snails collected from the 'Ardag' sediments were placed in aquaria with running seawater for at least $48 \mathrm{~h}$ (acclimation period, McKillup \& Butler 1983) prior to testing. Bioassays were conducted in triplicates in aluminum trays $(22 \times 18 \times 4 \mathrm{~cm})$ lined with a $1.5 \mathrm{~cm}$ layer of sand and filled with fresh seawater, and 20 min prior to the start of each bioassay 1 dead Sparus aurata fingerling (approx. $20 \mathrm{~g}$ ) was placed at one end of the tray. Subsequently, 12 snails were gently placed (if snails were dropped or handled roughly, they did not respond to the food, regardless of their hunger level) at the opposite side of the tray using forceps. The number of snails that reached the fish carrion within 20 min and began to feed was documented. Snails that commenced feeding before the bioassay ended were immediately removed from the tray. Fed ( $48 \mathrm{~h}$ prior to the bioassay) and starved ( 2 wk starvation) snails served as controls.
In a set of preliminary experiments, snails were fed fish carrion (Sparus aurata fingerlings) prior to starvation for different periods $(0,12,24,48,72$ and 168 $\mathrm{h}$ ), followed by the standard $48 \mathrm{~h}$ acclimation period, in order to assess the ability of this bioassay to test snail hunger level. These experiments included 5 replicates for each starvation period and were repeated on 3 separate occasions. The proportion of feeding snails/total snails increased as the period of starvation increased (Fig. 2). In order to test the attraction of snails to the farm $N$. sinusigerus were collected at each of the sampling stations in July 1998, October 1998 and in February 1999 and bioassayed, as above.

Statistical analysis. Statistical analyses were performed with the SAS statistical package (1999 version of SAS Software). Prior to ANOVA analysis Kolmogorov-Smirnov and Levene's tests were performed to test for normality and homogeneity of variance, respectively. Post-hoc multiple comparisons of means tested by Tukey's Studentized Range (HSD) test was applied to determine the effect of season and station on the geochemical variables and snail abundances. Spearman's Rank Correlations was used to test the relationships among the geochemical variables (performed on all data) and the relationships between the geochemical variables and snail abundances (performed on data collected between the farm and the area where the abundance peak was recorded). The geochemical data were further analyzed using $K$ means cluster-analysis (FASTCLUS procedure, SAS/STAT Software) calculated on transformed data, and subsequently the mean snail abundance was calculated for each cluster. The Kruskal-Wallis ANOVAby-ranks test was used to test snail hunger level with respect to distance from the fish farm.

\section{RESULTS}

\section{Water temperature, fish food input and hydrography}

Water temperature at $24 \mathrm{~m}$ depth was $21^{\circ} \mathrm{C}$ in April $1998,25^{\circ} \mathrm{C}$ in July and October 1998 and $22^{\circ} \mathrm{C}$ in February 1999. Average monthly fish food input for the entire fish farm was $253 \mathrm{t}$ for February to April 1998, $344 \mathrm{t}$ for May to July 1998, $359 \mathrm{t}$ for August to October 1998 and $204 \mathrm{t}$ for November 1998-February 1999. Mean current velocity was $3.7 \mathrm{~m} \mathrm{~s}^{-1}$ in April 1998, 12.2 $\mathrm{m} \mathrm{s}^{-1}$ in October 1998 and $13.8 \mathrm{~m} \mathrm{~s}^{-1}$ in February 1999. The current direction (affects distribution of particulate organic matter released from the farm) was east to west during 53, 96 and $46 \%$ of the time during current meter deployment in April 1998, October 1998 and February 1999, respectively. 


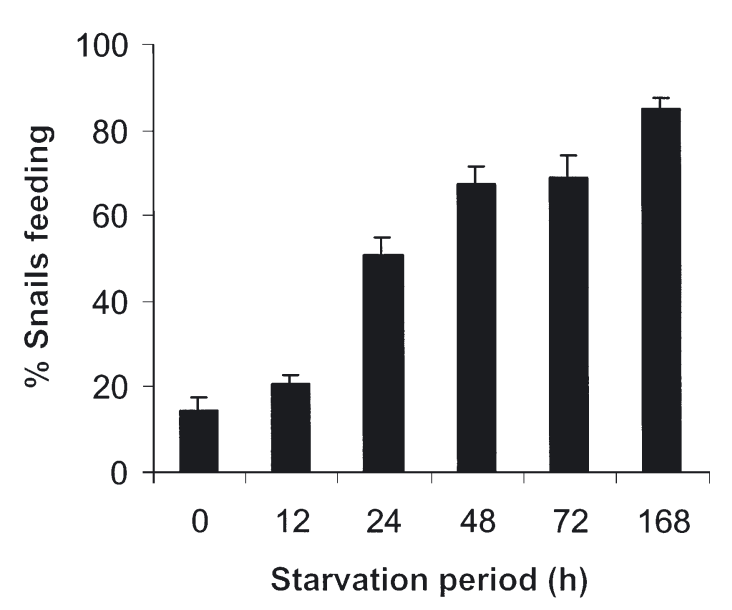

Fig. 2. Nassarius sinusigerus. Hunger ratio (\% snails that commenced feeding within 20 min of start of the bioassay) as a function of starvation period (defined as time in excess of $48 \mathrm{~h}$ after last feeding event). Data are means $( \pm \mathrm{SE})$ of 15 bioassays (12 snails per bioassay) for each starvation period

\section{Sediment geochemistry}

Sediments showed the greatest organic-enrichment impacts in the near vicinity of the fish farm, i.e. up to $40 \mathrm{~m}$ from the cages (Tables $1 \& 2$, Fig. 3). TDS values in the sediments closest to the farm exhibited the greatest seasonal fluctuations, and TDS concentrations in autumn were significantly higher than in all other seasons ( $p<0.05$; Tukey's Studentized Range Test). TDS concentrations in spring, summer and autumn decreased to zero $60 \mathrm{~m}$ from the farm, whereas practically no sulfide was detected along the transect in winter. DO concentrations at the sediment surface increased with increasing distance from the farm (Fig. 3). TDS concentrations and LOI levels were positively correlated with each other $(\mathrm{r}=0.699, \mathrm{~N}=38$, $\mathrm{p}<0.0001)$. Both variables were negatively correlated with DO concentrations $(\mathrm{r}=-0.796, \mathrm{~N}=39$, $\mathrm{p}<0.0001$ and $\mathrm{r}=-0.745, \mathrm{~N}=38, \mathrm{p}<0.0001$, respectively). A seasonal assessment of the data shows that in the vicinity of the fish farm, TDS and LOI levels were greatest in autumn, whereas DO concentrations were greatest in winter ( $\mathrm{p}<0.05$; Tukey's Studentized Range Test).

\section{Nassarius sinusigerus abundance and weight fluctuations}

Considerable variance was observed in snail abundances, both among seasons and among replicate samples within stations (Fig. 3). A peak in snail abundance was found on each sampling date in the region between 20 and $80 \mathrm{~m}$ west of the farm. A secondary increase in Nassarius sinusigerus abundance was also observed around 120 to $160 \mathrm{~m}$ west of the farm in spring and autumn 1998. In autumn 1998, snail abundances were greatest, yet the mean wet weight per snail $(12.2 \pm 2.0 \mathrm{mg})$ was significantly lower $(\mathrm{p}<0.05)$ than in all other seasons (Fig. 4). Conversely, in summer 1998, abundances were lowest and the mean wet weight per snail was highest $(29.2 \pm 8.9 \mathrm{mg})$. Skewness of the snail-weight frequency distribution towards juveniles in autumn 1998 (Fig. 4) suggests that a large recruitment event had occurred during the preceding summer.

\section{Nassarius sinusigerus distribution relative to geochemical variables}

Snail abundance at the stations beneath the farm and up to the area where the snail abundance peak was recorded was positively correlated with DO con-

Table 1. Seasonal comparisons among benthic geochemical variables: total dissolved sulfides (TDS), dissolved oxygen (DO) and sediment loss-on-ignition (LOI) between stations using Tukey's Studentized Range (HSD) Test. Different letters indicate differences significant at $\mathrm{p}<0.05$ level; 2 or 3 letters for a given variable at same station indicate large variance in values. Stn: stations, i.e. distance from farm $(\mathrm{m})$

\begin{tabular}{|c|c|c|c|c|c|c|c|c|c|c|c|c|c|}
\hline \multirow{2}{*}{ Stn } & \multicolumn{4}{|c|}{ TDS } & \multicolumn{5}{|c|}{ DO } & \multicolumn{4}{|c|}{ LOI } \\
\hline & Spring & Summer & Autumn & Winter & Spring & Summer & Autumn & & Winter & Spring & Summer & Autumn & Winter \\
\hline 0 & & A & A & $\mathrm{A}$ & A & A & A & $\mathrm{A}$ & & & A & A & A \\
\hline 20 & A B & B & A & A & A & A & A & $\mathrm{A}$ & & $\mathrm{A}$ & A & A & A \\
\hline 40 & A B & A & B & B & $\mathrm{A}$ & $\mathrm{A}$ & $\mathrm{A}$ & $\mathrm{A}$ & & $\mathrm{A}$ & B & B & B \\
\hline 60 & B & $\mathrm{C}$ & B & $\mathrm{A}$ & $\mathrm{A}$ & $\mathrm{A}$ & $\mathrm{A}$ & & B & B & $\mathrm{C}$ & $\mathrm{B} C$ & $\mathrm{C}$ \\
\hline 80 & B & $\mathrm{C}$ & B & $\mathrm{A}$ & A & $\mathrm{A}$ & $\mathrm{A}$ & & B C & B & C E & $\mathrm{CD}$ & $C D$ \\
\hline 100 & B & $\mathrm{C}$ & B & $\mathrm{A}$ & $\mathrm{A}$ & $\mathrm{A}$ & $\mathrm{A}$ & $\mathrm{A}$ & $\mathrm{C}$ & B C & C D E & $\mathrm{CD}$ & $\mathrm{C} \mathrm{D}$ \\
\hline 120 & B & $\mathrm{C}$ & B & $\mathrm{A}$ & $\mathrm{A}$ & $\mathrm{A}$ & A B & & C D & B C & $\mathrm{D}$ & $\mathrm{CD}$ & $\mathrm{D}$ \\
\hline 140 & B & $\mathrm{C}$ & B & $\mathrm{A}$ & B & $\mathrm{A}$ & B & & C D & $\mathrm{C}$ & $C D E$ & D & $\mathrm{D}$ \\
\hline 160 & & $\mathrm{C}$ & B & $\mathrm{A}$ & & B & B & & C D & & $C D E$ & $\mathrm{CD}$ & $\mathrm{C} \mathrm{D}$ \\
\hline 800 & B & $\mathrm{C}$ & B & A & B & B & A B & & $\mathrm{D}$ & B C & D E & $\mathrm{CD}$ & $\mathrm{CD}$ \\
\hline
\end{tabular}


Table 2. Sediment geochemical variables (mean $\pm \mathrm{SE}$ ) assigned to clusters using $K$-means cluster analysis (FASTCLUS procedure) and Nassarius sinusigerus abundance (mean $\pm \mathrm{SE}$ ) corresponding to each cluster. (Cluster analysis did not include N. sinusigerus abundance.) Stations and sampling seasons included in each cluster are also shown. Numbers in parentheses: number of observations; Cluster 1: highly impacted; Cluster 2: moderately impacted; Cluster 3: slightly impacted; spr: spring 1998; sum: summer 1998; aut: autumn 1998; win: winter 1999

\begin{tabular}{|c|c|c|c|}
\hline \multirow{2}{*}{ Variable } & \multicolumn{3}{|c|}{ Cluster } \\
\hline & 1 & 2 & 3 \\
\hline TDS & $5933 \pm 1271(17)$ & $17 \pm 6.6(81)$ & $0 \pm 0.0(35)$ \\
\hline DO & $0 \pm 0.0$ & $0.6 \pm 0.068(77)$ & $3.3 \pm 0.165(30)$ \\
\hline LOI & $6.1 \pm 0.355(16)$ & $2.3 \pm 0.093(75)$ & $1.5 \pm 0.062(29)$ \\
\hline Snail abundance $\mathrm{m}^{-2}$ & $119 \pm 39(13)$ & $2364 \pm 330(75)$ & $1241 \pm 329(29)$ \\
\hline \multirow[t]{10}{*}{ Stations included } & Stn $0 ; \operatorname{sum}(2)$ aut(4) & Stn $0 ; \operatorname{spr}(3) \operatorname{sum}(2) \operatorname{win}(4)$ & Stn $40 ;$ aut(1) \\
\hline & Stn 20; $\operatorname{sum}(4)$ aut(4) & Stn 20; $\operatorname{spr}(3)$ win(2) & Stn 60; aut(1) win(3) \\
\hline & $\operatorname{Stn} 40 ; \operatorname{sum}(3)$ & Stn $40 ; \operatorname{spr}(3) \operatorname{sum}(1)$ aut(3) win(3) & Stn 80; win(3) \\
\hline & & Stn 60; $\operatorname{spr}(3) \operatorname{sum}(4)$ aut(3) win(3) & Stn $100 ; \operatorname{win}(2)$ \\
\hline & & Stn 80; $\operatorname{spr}(3) \operatorname{sum}(4)$ aut(4) & Stn 120; aut(1) win(3) \\
\hline & & Stn 100; $\operatorname{spr}(3) \operatorname{sum}(4)$ aut(4) win(1) & Stn 140; spr(2) aut(3) win(3) \\
\hline & & Stn 120; spr(3) sum(4) aut(3) & Stn 160; sum(2) aut(3) win(3) \\
\hline & & Stn 140; spr(1) sum(3) aut(1) & $\operatorname{Stn} 800 ; \operatorname{spr}(3) \operatorname{sum}(3) \operatorname{win}(3)$ \\
\hline & & Stn 160; sum(2) aut(1) & \\
\hline & & Stn $800 ; \operatorname{spr}(1) \operatorname{sum}(1)$ aut(4) & \\
\hline
\end{tabular}

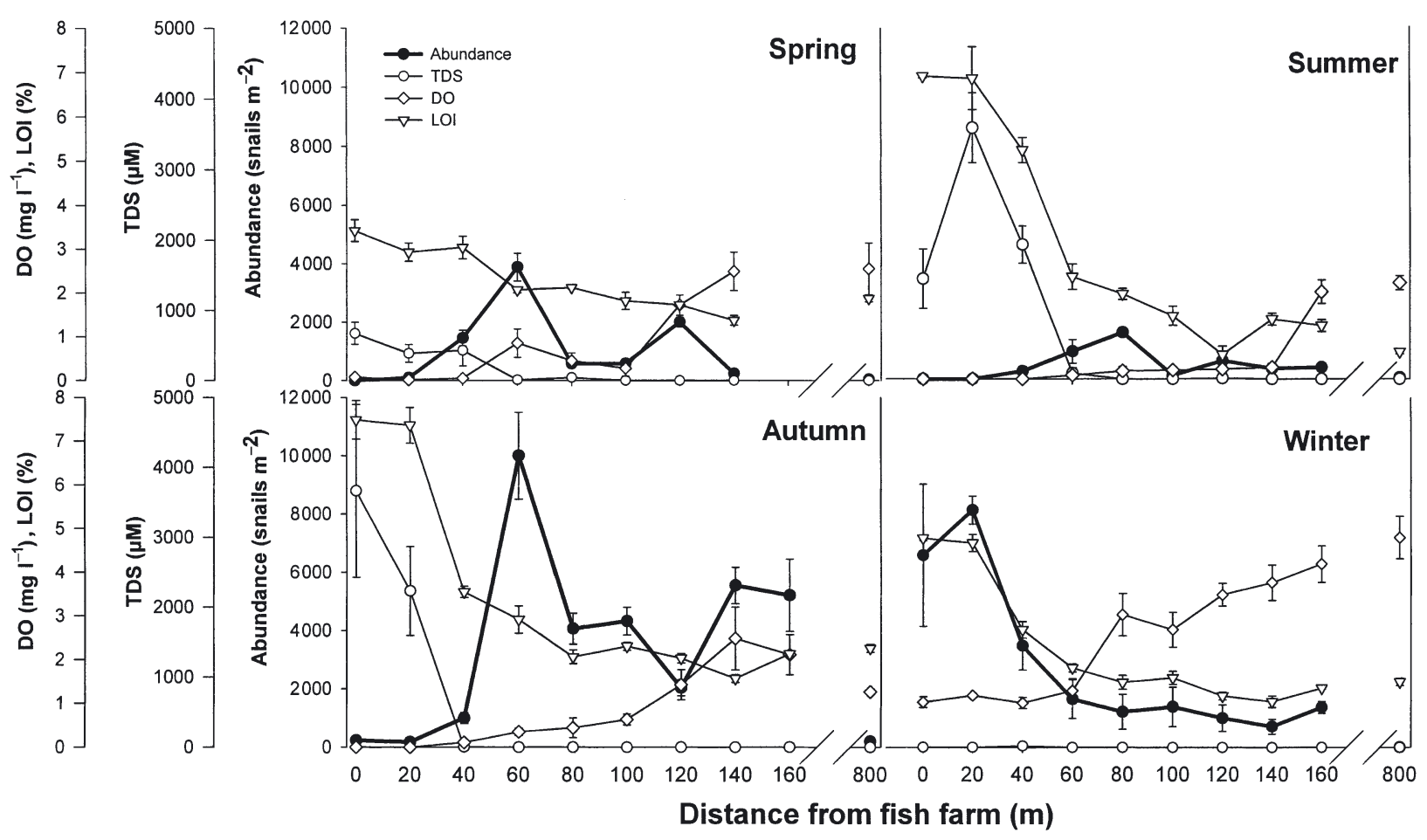

Fig. 3. Summary of sediment geochemistry and snail (Nassarius sinusigerus) abundance at each station in April (spring), July (summer), October (autumn) 1998 and February (winter) 1999. Geochemical variables comprised total dissolved sulfides (TDS) and loss-on-ignition (LOI) in upper $2 \mathrm{~cm}$ of sediment and dissolved oxygen (DO) at sediment surface. All data are means of at least 3 replicates $( \pm \mathrm{SE})$

centration ( $\mathrm{r}=0.829, \mathrm{~N}=15, \mathrm{p}<0.01)$ and inversely correlated with $\mathrm{H}_{2} \mathrm{~S}$ concentration $(\mathrm{r}=-0.767, \mathrm{~N}=15$, $\mathrm{p}<0.001$ ). However, there was no significant correlation between snail abundance and LOI levels. Peak abundances of Nassarius sinusigerus occurred where $\mathrm{H}_{2} \mathrm{~S}$ concentrations in the upper $2 \mathrm{~cm}$ of the sediment dropped below $1 \mu \mathrm{M}$ and DO concentrations exceeded $0.3 \mathrm{mg} \mathrm{l}^{-1}$. In winter, when geochemical conditions in 


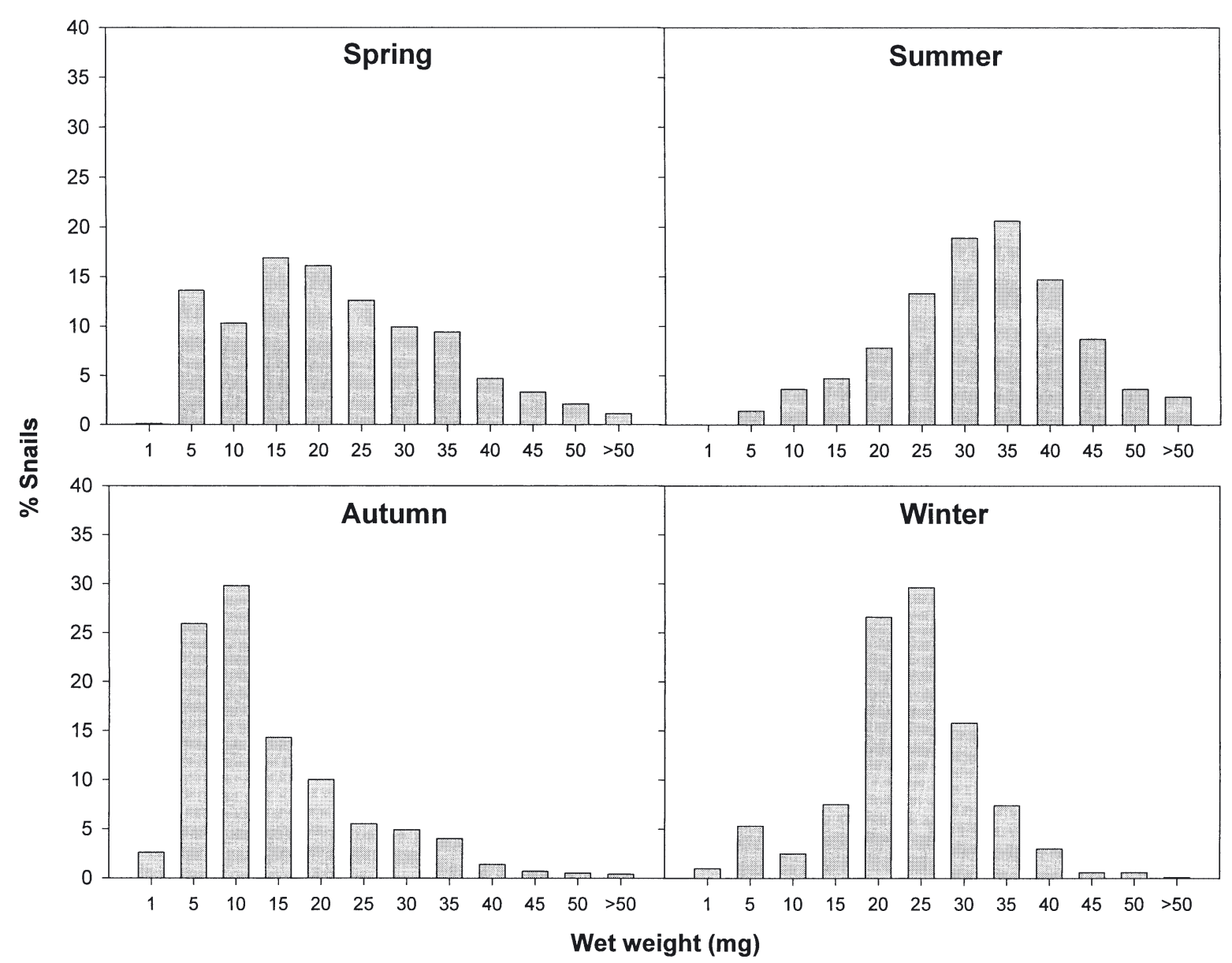

Fig. 4. Nassarius sinusigerus. Mean wet weight distribution in April (spring), July (summer), October (autumn) 1998 and February (winter) 1999

the sediments below the fish cages improved $\left(\mathrm{H}_{2} \mathrm{~S}=0\right.$; DO $>1 \mathrm{mg} \mathrm{l}^{-1}$ from below the farm onwards), the snail abundance peak shifted toward the farm.

The geochemical data (TDS, DO and LOI) from all seasons and all stations were analyzed by $K$-means cluster analysis and this procedure revealed 3 distinct groupings ( $\mathrm{p}<0.001)$ which we have coined: 'highly' (Cluster 1), 'moderately' (Cluster 2) and 'slightly' (Cluster 3) impacted sediments (Table 2). The highly impacted sediments (Cluster 1 ) were in the immediate vicinity of the fish farm (0 to $40 \mathrm{~m}$ ) during summer and autumn, whereas Clusters 2 and 3 were mainly comprised of samples from more distant stations. Because sediment conditions were better during winter and spring, Cluster 2 (moderately impacted) includes data from Stns 0 to 40 as well. A few samples from the highly impacted stations fell into the moderately and slightly impacted clusters (see Table 2) as a result of high LOI and low TDS or low DO within the same sample. It is noteworthy that snail abundances in Clusters 2 and 3 were significantly higher than those recorded in Cluster 1 ( $p<0.001)$, but were not significantly different from each other. The highest abundances of snails (abundance peaks) corresponded to conditions that characterized the sediments in Cluster 2.

\section{Nutritional behavior of Nassarius sinusigerus}

Snails collected in the field, at distances $\geq 60 \mathrm{~m}$ from the fish farm, displayed significantly higher 'hunger ratios' (HR; proportion of feeding snails/total snails) than snails collected closer to the farm $(p<0.05)$ (Fig. 5). There were no significant differences in the hunger ratios of snails sampled from between 60 and $160 \mathrm{~m}$ from the farm. The HR of snails collected below the cages (Stn 0) was not significantly different from the HR of fed snails. At all stations (except for snails collected $120 \mathrm{~m}$ from the farm) the 'hunger ratios' of Nassarius sinusigerus were significantly lower than those of starved snails $(p<0.05)$. Snails that were fed just prior to the bioassays (the 'fed' control) did not 
feed on the carrion in the bioassay, whereas $89 \%$ of the starved snails reached the fish carrion and commenced feeding within $20 \mathrm{~min}$.

\section{DISCUSSION}

The highly impacted sediments at the 'Ardag' fish farm were restricted to the area below the cages (Sampling Stns 0 and $20 \mathrm{~W}$ ), as documented in similar fish farm impact studies elsewhere (Weston 1990, Ye et al. 1991, Holmer \& Kristensen 1992, Karakassis et al. 1998). The sediments surrounding the highly impacted region could be described as 'transitional' (Angel et al. 1995), since they exhibit variable geochemistries (Fig. 3) and respond to seasonal changes. It is likely that the seasonal changes in the area of impacted seafloor surrounding the 'Ardag' farm were related to the combined effects of seasonal adjustment in fishfeed input and changes in local hydrography (Brenner et al. 1988, 1991) that affect the distribution of fish farm effluents (e.g. Holmer \& Kristensen 1992, 1996, Karakassis et al. 1998). Our data indicate the need for seasonal sampling to characterize sediment status in regions where seasonal variability occurs. Although several studies have documented seasonal variations in benthic communities under fish farms (Hargrave et al. 1993, 1997, Findlay et al. 1995, Tsutsumi 1995), this is the first report of seasonal spatial shifting in distribution (abundance peak) of a benthic species in relation to the level of organic enrichment.

We propose that the unique benthic conditions created by the fish farm served as both attractant and deterrent to Nassarius sinusigerus. Pearson \& Rosenberg $(1978,1987)$ regarded food availability as an

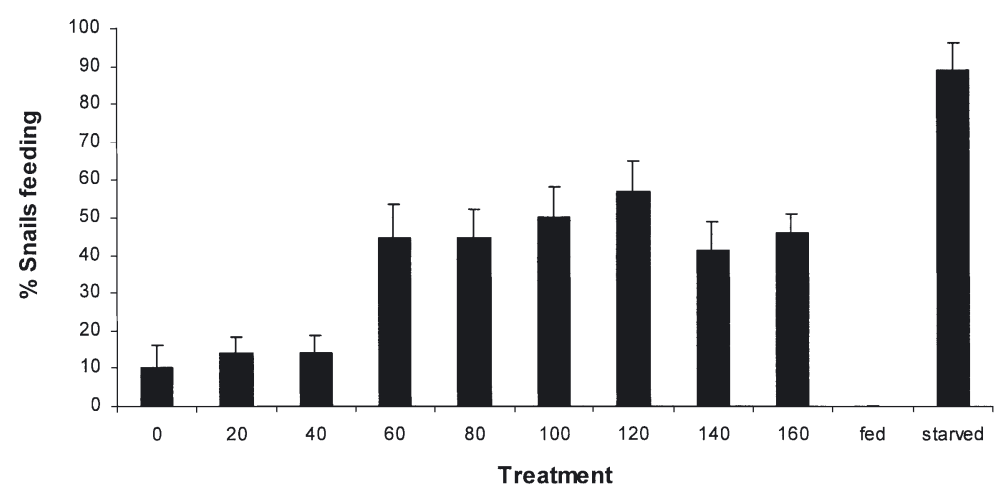

Fig. 5. Nassarius sinusigerus. Mean $( \pm \mathrm{SE})$ hunger ratio: $\%$ snails that commenced feeding within 20 min of start of bioassay of total number in each bioassay (12 snails). Treatment: snails were collected at $20 \mathrm{~m}$ intervals, from 0 to $160 \mathrm{~m}$ west of the 'Ardag' fish farm for the bioassays $(\mathrm{N}=$ between 9 and 12 bioassays per station). Hunger ratios of fed $(\mathrm{N}=6$ bioassays) and starved ( 2 wk starvation) snails ( $\mathrm{N}=3$ bioassays) are also presented attractant for opportunistic species, and sediment toxicity as a barrier that prevents them from advancing further toward the attractant. Whereas $N$. sinusigerus can tolerate fairly high levels of $\mathrm{H}_{2} \mathrm{~S}$ and hypoxia (Fig. 3), the greatest snail abundances were found in moderately impacted conditions (Table 2). The factor attracting $N$. sinusigerus toward the farm was probably food availability, as indicated by the hunger bioassays (Fig. 5) and the strong attraction of the snails to fish-farm sediments, and to annelids in these sediments (T. Katz unpubl. data). This behavior is not unique to $N$. sinusigerus, as similar carniverous scavenging feeding activity has been reported for other nassarid species (Tallmark 1980, Britton \& Morton 1992). Moreover, an increase in nassariid abundance was recorded where fishery bycatches had been dumped (i.e. an increase in carrion availability) in Hong Kong coastal waters (Britton \& Morton 1994).

Pearson \& Rosenberg (1978) suggested that the peak of opportunists could serve as a monitoring tool to assess the extent of impact on the benthos. An increase in distance between this peak and the source of organic enrichment would indicate deterioration in environmental conditions around the fish farm (as observed in this study in summer 1998), whereas a shift in the peak toward the source would reflect reduction in the environmental impact (as observed in winter 1999). Since Nassarius sinusigerus is an opportunistic species with a typical distribution pattern along an organic enrichment gradient, we suggest that the position of peak abundances along the transect may indicate the level of benthic organic enrichment. It should be noted that the effect of predation on nassariid population dynamics and distribution is presently unknown and should be examined in future research.

In a long-term benthic study at an ocean sewage outfall, Maurer et al. (1993) tested the validity of the Pearson \& Rosenberg (1978) model. The peak in macrobenthos abundance coincided with the highest concentrations of total organic carbon, i.e. macrobenthos did not decline with increasing organic load, as predicted by the model. The abundance pattern described by Maurer et al. (1993) resembles our winter 1999 observations when the sediment geochemical conditions improved, enabling the highest Nassarius sinusigerus abundances to occur directly under the fish farm despite the high LOI levels there. Thus, we suggest that when the macrobenthos abundance peak approached the point source of organic enrichment (fish farm), the sediment conditions had not reached detrimental levels for the studied organisms. 
It appears that one of the main factors that determines the magnitude of the snail abundance peak is the time lapsed since the last recruitment event. There was evidently a large recruitment event in late summer 1998, as indicated by the skewness of the snailweight frequency distribution towards juveniles in autumn 1998 (Fig. 4). This phenomenon also recurred during autumn 1999 and autumn 2000 (N. Eden unpubl. data). Previous studies on the population dynamics of nassariids have shown considerable seasonal and year-to-year fluctuations in abundance (Tallmark 1980). Moreover, spawning of several nassariid species-Nassarius reticulatus (Tallmark 1980), N. obsoletus (Scheltema 1967, Sastry 1970) and N. trivittatus (Pechenik 1978) - is clearly linked to water temperature and the availability of organically rich substratum. It is possible that the major recruitment of $N$. sinusigerus occurs during summer, but that the additional food resources in the vicinity of the fish farm support constant low levels of recruitment throughout the year (Fig. 4). In light of the strong seasonal differences in snail abundance (Fig. 3), we propose that the environmental indicator should be the position of the peak in snail abundance along the transect, rather than the actual number of snails per unit area.

The results of this study suggest that the distribution of Nassarius sinusigerus around fish farms is determined by the balance between sediment geochemistry $\left(\mathrm{H}_{2} \mathrm{~S}\right.$ and DO concentrations) and the attraction of the gastropod to the organically enriched sediments below the fish cages. As such, the distribution of $N$. sinusigerus may serve as an indicator of sediment conditions. In an independent study of the sediments under various salmon farms in Chile, A. Clemente (pers. comm.) observed that the local nassarid $N$. denifer exhibited peak abundances (up to 25000 snail $\mathrm{m}^{-2}$ ) in the transition zone between moderate and low benthic impact (see also www.aquatoxsal.de). Since nassarids are cosmopolitan gastropods, their response to fish-cage aquaculture should be considered a potential biological indicator for the state of marine sediments around such operations.

Acknowledgements. We acknowledge the generous help that enabled us to carry out the research and improve this manuscript: Henk Mienis for the identification of Nassarius sinusigerus; Fidi Kopel and Gitai Yahel for help with statistics; Amatzia Genin and Steve Brenner for their help with current meters; Roi Holzman, Uri Segal, Ayana Bennet and Adi Peduel for field and laboratory assistance; members of the Ardag fish farm for providing fish-feed data and access to the study site; Hanna Bernard for help in drafting the site map (Fig. 1); Dani Zuber, who was the first to observe increased abundances of these snails near the Ardag fish farm; and Debbie Lindell and 4 anonymous reviewers for their helpful comments on drafts of the manuscript.

\section{LITERATURE CITED}

Angel DL, Krost P, Gordin H (1995) Benthic implications of net cage aquaculture in the oligotrophic Gulf of Aqaba. Spec Publ Eur Aquac Soc 25:129-173

Beveridge MCM (1996) Cage aquaculture. Fishing News Books, Oxford

Boyd CE (1990) Water quality in ponds and aquaculture. Birmingham Publishing Company, Birmingham, AL, p 88-89

Brenner S, Rosentroub Z, Bishop Y (1988) Current measurements in the Gulf of Elat. Report H3/88, Israel Oceanographic and Limnological Research, Haifa

Brenner S, Rosentroub Z, Bishop Y (1991) Current measurments in the Gulf of Elat 1990/91. Report H12/91, Israel Oceanographic and Limnological Research, Haifa

Britton JC, Morton B (1992) The ecology and feeding behaviour of Nassarius festivus (Prosobranchia:Nassariidae) from two Hong Kong bays. In: Morton B (ed) The marine flora and fauna of Hong Kong and Southern China III. Proceedings of the Fourth International Marine Biological Workshop on the Marine Flora and Fauna of Hong Kong and Southern China. Hong Kong University Press, p 395-416

Britton JC, Morton B (1994) Marine carrion and scavengers. Oceanogr Mar Biol Annu Rev 32:369-434

Brown JR, Gowen RJ, McLusky DS (1987) The effect of salmon farming on the benthos of a Scotitish sea loch. J Exp Mar Biol Ecol 109:39-51

Ferraro SP, Swartz RC, Cole FA, Schults DW (1991) Temporal changes in the benthos along a pollution gradient: discriminating the effects of natural phenomena from sewageindustrial wastewater effects. Estuar Coast Shelf Sci 33: 383-407

Findlay RH, Watling L, Mayer LM (1995) Environmental impact of salmon net-pen culture on marine benthic communities in Maine: a case study. Estuaries 18:145-179

Fishelson L (1971) Ecology and distribution of the benthic fauna in the shallow waters of the Red Sea. Mar Biol 10: 113-133

Gowen RJ, Weston DP, Ervik A (1991) Aquaculture and the benthic environment: a review. In: Cowey $\mathrm{CB}$, Cho $\mathrm{CY}$ (eds) Nutritional strategies and aquaculture waste. Proceedings of the First International Symposium on Nutritional Strategies in Management of Aquaculture Waste. University of Guelph, Ontario, p 187-205

Hargrave BT, Duplisea DE, Pfeiffer E, Wildish DJ (1993) Seasonal changes in benthic fluxes of dissolved oxygen and ammonium associated with marine cultured Atlantic salmon. Mar Ecol Prog Ser 96:249-257

Hargrave BT, Phillips GA, Doucette LI, White MJ, Milligan TG, Wildish DJ, Cranston RE (1997) Assessing benthic impacts of organic enrichment from marine aquaculture. Water Air Soil Pollut 99:641-650

Holmer M, Kristensen E (1992) Impact of marine fish cage farming on metabolism and sulfate reducing of underlying sediments. Mar Ecol Prog Ser 80:191-201

Holmer M, Kristensen E (1996) Seasonality of sulfate reduction and pore water solutes in a marine fish farm sediment: the importance of temperature and sedimentary organic matter. Biogeochemistry 32:15-39

Karakassis I, Tsapakis M, Hatziyanni E (1998) Seasonal variability in sediment profiles beneath fish farm cages in the Mediterranean. Mar Ecol Prog Ser 162:243-252

Karakassis I, Tsapakis M, Hatziyanni E, Papadopoulou KN, Plaiti W (2000) Impact of cage farming of fish on the seabed in three Mediterranean coastal areas. ICES J Mar Sci 57:1462-1471 
Katz T, Herut B, Genin A, Angel DL (2002) Gray mullets ameliorate organically enriched sediments below a fish farm in the oligotrophic Gulf of Aqaba (Red Sea). Mar Ecol Prog Ser 234:205-214

Maurer D, Robertson G, Gerlinger T (1993) San Pedro Shelf California: testing the Pearson-Rosenberg Model (PRM). Mar Environ Res 35:303-321

McKillup C, Butler AJ (1983) The measurement of hunger as a relative estimate of food available to populations of Nassarius pauperatus. Oecologia 56:16-22

Morely JH (1995) Spatial and temporal effects of organic enrichment on meiobenthos. PhD thesis, University of Tasmania, Hobart

Pearson TH, Black KD (2001) The environmental impacts of marine fish cage culture. In: Black KD (ed) Environmental impacts of aquaculture. Sheffield Academic Press, Sheffield, p 1-31

Pearson TH, Rosenberg R (1978) Macrobenthic succession in relation to organic enrichment and pollution of the marine environment. Oceanogr Mar Biol Annu Rev 16:229-311

Pearson TH, Rosenberg R (1987) Feast and famine: structuring factors in marine benthic communities. In: Gee JHR, Giller PS (eds) Organization of commutinies, past and present. Proc 27th Symp Br Ecol Soc, Aberystwyth. Blackwell Scientific Publications, London, p 373-395

Pechenik JA (1978) Winter reproduction in the gastropod Nassarius trivittatus. Veliger 2:297-298

Reiss Z, Hottinger L (1984) The Gulf of Aqaba: ecological micropaleontology. Springer-Verlag, New York

Sastry AN (1970) Effect of temperature on egg capsule deposition in the mud snail Nassarius obsoletus (Say). Veliger 13:339-341

Scheltema RS (1967) The relationship of temperature to the

Editorial responsibility: Kenneth Tenore (Contributing Editor), Solomons, Maryland, USA larval development of Nassarius obsoletus (Gastropoda). Biol Bull (Woods Hole) 132:253-265

Singer BS, Mienis HK (1997) The family Nassaridae of the Red Sea (Part II). Conchiglia 29:36-43

Swartz RC, Cole FA, Schults DW, DeBen WA (1986) Ecological changes in the Southern California Bight near a large sewage outfall: benthic conditions in 1980-1983. Mar Ecol Prog Ser 31:1-13

Tallmark B (1980) Population dynamics of Nassarius reticulatus (Gastropoda, Prosobranchia) in Gullmar Fjord, Sweden. Mar Ecol Prog Ser 3:51-62

Tsutsumi H (1995) Impact of fish net pen culture on the benthic environment of a cove in South Japan. Estuaries 18: 108-115

Tsutsumi H, Fukunaga S, Fujita N, Sumida M (1990) Relationship between growth of Capitella sp. and organic enrichment of the sediment. Mar Ecol Prog Ser 63: $157-162$

Tsutsumi H, Kikuchi T, Tanaka M, Higashi T, Imasaka K, Miyazaki M (1991) Benthic faunal succession in a cove organically polluted by fish farming. Mar Pollut Bull 23: 233-238

Visscher PT, Beukema J, van Gemerden H (1991) In situ characterization of sediments: measurements of oxygen and sulfide profiles with a novel combined needle electrode. Limnol Oceanogr 36:1476-1480

Weston DP (1990) Qualitative examination of macrobenthic community changes along an organic enrichment gradient. Mar Ecol Prog Ser 61:233-244

Ye L, Ritz DA, Fenton GE, Lewis ME (1991) Tracing the influence on sediments of organic waste from a salmonid farm using stable isotope analysis. J Exp Mar Biol Ecol 145: 161-174

Submitted: March 22, 2002; Accepted: August 5, 2003 Proofs received from author(s): November 10, 2003 